\title{
Market access, population density, and socioeconomic development explain diversity and functional group biomass of coral reef fish assemblages
}

\author{
Tom D. Brewer ${ }^{\mathrm{a}, *}$, Joshua E. Cinner ${ }^{\mathrm{a}}$, Rebecca Fisher ${ }^{\mathrm{b}}$, Alison Green ${ }^{\mathrm{c}}$, Shaun K. Wilson ${ }^{\mathrm{d}, e}$ \\ ${ }^{a}$ Australian Research Council Centre of Excellence for Coral Reef Studies, James Cook University, Townsville, QLD 4811, Australia \\ ${ }^{\mathrm{b}}$ Australian Institute of Marine Science, UWA Oceans Institute (M004), 35 Stirling Hwy, Crawley 6009, Australia \\ ${ }^{\mathrm{c}}$ The Nature Conservancy, 51 Edmonstone Street, Brisbane 4101, Australia \\ ${ }^{\mathrm{d}}$ Marine Science Program, Department of Environment and Conservation, 17 Dick Perry Ave, Kensington 6151, Australia \\ ${ }^{\mathrm{e}}$ Oceans Institute, University of Western Australia, Crawley 6009, Australia
}

\section{A R T I C L E I N F O}

\section{Article history:}

Received 23 September 2011

Received in revised form 24 January 2012

Accepted 26 January 2012

Available online 23 February 2012

\section{Keywords:}

Distal driver

Proximate driver

Fishing pressure

Coral cover

Structural equation model

Trade

\begin{abstract}
A B S T R A C T
There is overwhelming evidence that many local-scale human activities (e.g. fishing) have a deleterious effect on coral reef fish assemblages. Our understanding of how broad social phenomena (e.g. socioeconomic development) affect the diversity and function of coral reef fish assemblages however, is still poor. Here, we use structural equation models to reveal how human population density, socioeconomic development, and market access affect fishing pressure and coral cover to, in turn, explain the diversity and biomass of key functional groups of reef fish assemblages within Solomon Islands. Fishing pressure is predominantly driven by both market access and local population density, and has a clear negative effect on the diversity and function of coral reef fishes. The strong positive effect of market access on fishing pressure makes clear the importance of understanding social-ecological linkages in the context of increasingly connected societies. This study highlights the need to address broad social phenomena rather than focusing on proximate threats such as fishing pressure, to ensure the continued flow of coral reef goods and services in this time of rapid global social and environmental change.
\end{abstract}

(c) 2012 Elsevier Ltd. All rights reserved.

\section{Introduction}

There is overwhelming evidence that human activities are profoundly altering marine ecosystems on a global scale (e.g. Hughes, 1994; Pandolfi et al., 2003). Of particular concern are the poorly understood, yet potentially disastrous environmental changes that human activity is causing to the functioning of coral reef ecosystems upon which millions of people depend (Mora et al., 2011). Ecosystem function is conceptually and analytically complex, requiring a diverse array of metrics to understand ecosystem response to human activity. High biological diversity is thought to contribute to maintaining ecosystem resilience (e.g. McCann, 2000; Cardinale et al., 2006; Tilman et al., 2006) through increased response diversity to perturbations and functional redundancy (Naeem, 1998; Chapin et al., 2000; Hooper et al., 2005; Maestre et al., 2012; but see Ives and Carpenter, 2007), assuming that species respond to threats uniquely. The use of diversity metrics as surrogates for ecosystem function however, does not come without criticism. There is, for example, some evidence that particular species (Bellwood et al., 2003, 2006; Hoey

\footnotetext{
* Corresponding author. Tel.: +61 433976561.

E-mail address: tomdbrewer@gmail.com (T.D. Brewer).
}

and Bellwood, 2009), and functional groups (e.g. Hughes et al., 2007) perform disproportionately important functional roles, acting as energy conduits through trophic levels and maintaining broader ecosystem processes. Therefore, it is important to consider measures of both diversity and functional groups to understand how ecosystems may respond to human activities.

Coral reef fish are perhaps the most diverse of vertebrate communities, are vital to ecosystem function, and provide significant goods and services to people. A range of factors have been identified as important drivers of the diversity, biomass, and abundance of reef fish functional groups. At large biogeographic scales, distributions of diversity and function can be explained by environmental factors, including available habitat, latitudelongitude gradients, the mid-domain effect, gyre influence, history of environmental stress, and larval subsidy from species-rich regions (Bellwood and Hughes, 2001; Connolly et al., 2003; Mora et al., 2003; Bellwood et al., 2005; Mora and Robertson, 2005; McClanahan et al., 2011). At local and national socio-political scales, various environmental and social factors have been used to explain fish diversity and biomass of functional groups. Environmental factors include depth, exposure to prevailing weather, season, reef zone, coral cover, substrate rugosity, habitat complexity, and larval dispersal (Luckhurst and Luckhurst, 1978; Molles, 1978; Bell and Galzin, 1984; Roberts and Ormond, 1987; 
Friedlander and Parrish, 1998; Friedlander et al., 2003; Gratwicke and Speight, 2005; Jones et al., 2005; Graham et al., 2006) (Table 1). In contrast to the depth of work assessing environmental drivers of fish diversity and function, assessments of the potentially important role that human activity might have in shaping ecological assemblages have focused largely on human population density (Jennings et al., 1995; Jennings and Polunin, 1996, 1997; Bellwood et al., 2003; Dulvy et al., 2004a,b; Mora, 2008; Williams et al., 2008, 2011; Stallings, 2009) and fishing pressure (DeMartini et al., 2008; Wilson et al., 2008). However, recent research has highlighted the potentially important role of factors such as market access and socioeconomic development in explaining functional group distributions (Aswani and Sabetian, 2009; Brewer et al., 2009; Cinner et al., 2009a; Stallings, 2009). What is not clear, however, is how market access and socioeconomic development affect fish species diversity, and whether market access and socioeconomic development have an effect on fish diversity and function beyond what is explained by human population density. This paper aims to contribute to this research gap by examining relationships between social drivers and the diversity and function of reef fish communities.

Social scientists working on human-environment interactions often differentiate between proximate (e.g. fishing pressure) and distal (e.g. market access, socioeconomic development, and human population density) drivers of environmental degradation (Forester and Machlis, 1996; Agrawal and Yadama, 1997; Geist and Lambin, 2002; Kramer et al., 2009; McKinney et al., 2010). In a coral reef context, there is clear evidence that, at the local-scale, people directly affect coral reef fish diversity and function through proximate drivers such as fishing pressure and habitat degradation (Wilson et al., 2008). What is not clear, however, is the role of distal drivers, in shaping these proximate drivers and ultimately coral reef fish diversity and function. For example, increased socioeconomic development does not directly affect fish diversity and function, but might intensify local fishing pressure through greater access to more efficient fishing gear, which might, in turn, decrease diversity and function of coral reef fish. Alternatively, increased socioeconomic development might reduce dependence on local resources, or enable improved resource management practices, resulting in increased fish diversity and function (Cinner et al., 2009a).

Here, we explore the linkages between three recognized distal drivers (population density, socioeconomic development and market access), two proximate drivers (fishing pressure and coral cover), and a range of metrics of fish diversity and function. We use structural equation models to understand the sequential effects of distal drivers on proximate drivers, and proximate drivers on diversity and function metrics across 25 sites in Solomon Islands.

Solomon Islands is a low-income nation with exceptionally high fish species diversity (Green et al., 2006a). The vast majority of the rapidly growing population lives along the coastline throughout the multitude of islands which comprise the nation. Reef fish and fishing are significant to Solomon Islands livelihoods, yet future demand for fish is expected to exceed ecological replenishment (Bell et al., 2009). Increasing market access, and evidence of declining fish biomass with increasing market proximity (ANU Enterprise, 2008), particularly for certain taxonomic groups (Brewer et al., 2009), suggest that fishing pressure, and associated social and economic change, contribute to variability in the distribution of reef fish diversity and function. By assessing and comparing the effect of distal and proximate drivers on reef fish assemblages this study quantifies the relative importance of these social drivers in a diverse ecological system.

\section{Methods}

\subsection{Site selection and delineation}

The 25 sites in this study span seven of the nine provinces in Solomon Islands (Fig. 1). We collected both ecological and social

Table 1

Key environmental and human factors that explain in situ coral reef fish diversity and functional group distributions at biogeographic scales relevant to this study.

\begin{tabular}{|c|c|c|c|}
\hline Factor & Explains diversity measures $^{\mathrm{a}}$ & Explains functional group biomass ${ }^{\mathrm{b}}$ & Controlled for in this study? \\
\hline \multicolumn{4}{|l|}{ Environmental } \\
\hline Depth & $1,2,3 .^{\mathrm{c}}$ & 1,3 & $S^{d}$ \\
\hline Exposure & 4. & 11,12 & $\mathrm{~S}$ \\
\hline Time & 5. & - & $\mathrm{S}$ \\
\hline Reef zone & 1. & 1,13 & $\mathrm{~S}$ \\
\hline$\%$ Coral cover & 6,7 & $1,3,7$ & $\mathrm{M}^{\mathrm{e}}$ \\
\hline Habitat complexity & $4,8,9$ & $9,14$. & $* \mathrm{f}$ \\
\hline Habitat rugosity ${ }^{\mathrm{g}}$ & $1,4,10$ & 1,15 & $*$ \\
\hline \multicolumn{4}{|l|}{ Human } \\
\hline \multicolumn{4}{|l|}{ Proximate drivers } \\
\hline Fish consumption & - & 14. & $\mathrm{M}$ \\
\hline Fishing pressure & 16. & 16, 19, 20 & $\mathrm{M}$ \\
\hline \multicolumn{4}{|l|}{ Distal drivers } \\
\hline Population density & 17,18 & $15,17,18,21-26$ & $\mathrm{M}$ \\
\hline Affluence & - & $15,18^{\mathrm{h}}$ & $\mathrm{M}$ \\
\hline Urban development & - & 24,27 & M \\
\hline Market access & - & 28. & $\mathrm{M}$ \\
\hline
\end{tabular}

\footnotetext{
a References relate to any measure of diversity (e.g. richness, evenness).

b References relate to any functional group abundance or biomass measure (e.g. herbivore biomass) show, statistically, the effect of the factors listed, on measures of coral reef fish diversity or function.

d Controlled during sampling.

e Controlled in model.

f Correlated with coral cover (Graham et al., 2008).

g Also measured as number of 'holes' and hole volume of reef substrate (Friedlander and Parrish, 1998).

h Not significantly correlated.
}

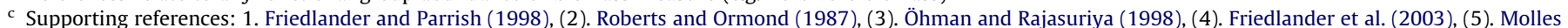

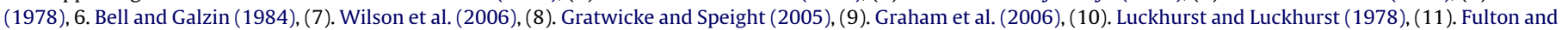

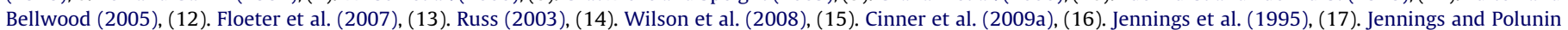

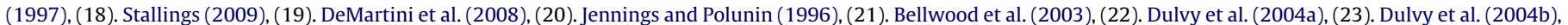

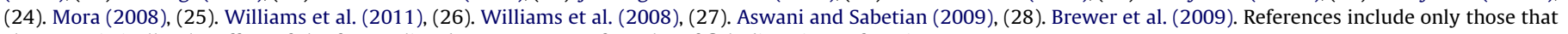




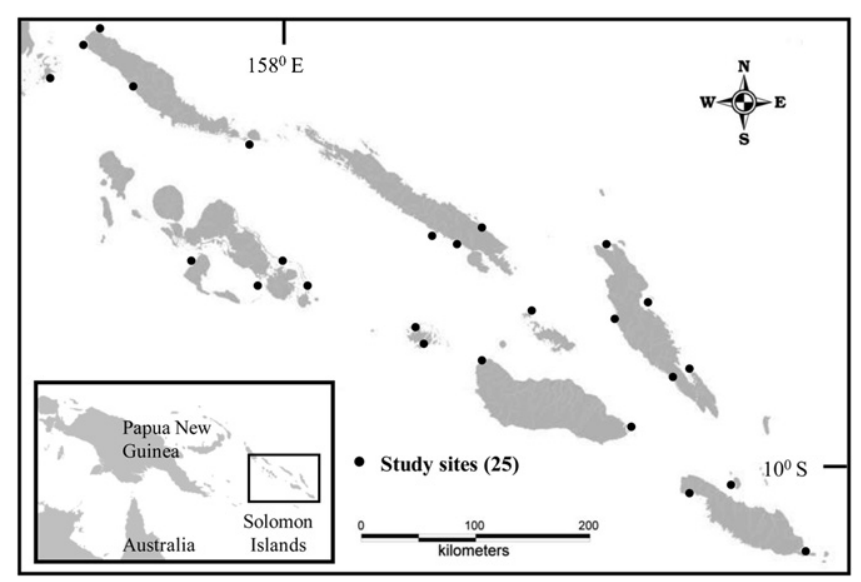

Fig. 1. The main islands of Solomon Islands including site locations.

data for each site. Site locations were predetermined by a marine assessment which surveyed both reef fish populations and coral substrate (Green et al., 2006a). It was necessary to define the spatial extent of each site to determine which human populations were associated with the coral reef at the location where the marine assessment occurred. The spatial extent of each site was elicited from individuals possessing local knowledge of resource use by people residing in adjacent villages. The marine boundary was defined as the area, within the vicinity of where the fish were surveyed, which was likely to be exploited by people living in villages on the adjacent coastline (Brewer et al., 2009). Alternative methods exist for estimating resource use boundaries, including friction mapping using thiessen polygons (Muller and Zeller, 2002), ethnographic studies (Aswani, 1999), and participatory GIS mapping (Aswani, 2011). However, the large-scale nature of this study inhibited the use of these more localized resource use mapping techniques. Our approach made use of the best available information at the spatial scale of our study. The terrestrial boundary of each site was set at $1 \mathrm{~km}$ from the coastline, extending along the coast to where the marine area boundary intersected the coast. Social data on villages within the aforementioned boundaries was provided by the Solomon Islands statistics office and derived from a national census (1999), and a national village resource survey (2007/2008).

\subsection{Ecological response variables}

Fish species used in this study included all fishes surveyed across the 25 sites (ESM 1). Fish were surveyed, from May to June 2004, using underwater visual census along five $50 \mathrm{~m}$ transects at each site, at a depth of 8-10 $\mathrm{m}$ on reef slope in locations exposed to prevailing weather conditions (Green et al., 2006b). Four metrics of species diversity were used to test the effect of proximate and distal drivers on fish diversity; (1) species richness, (2) Pielou's species evenness, (3) average taxonomic distinctness (AvTD), and (4) variation in taxonomic distinctness (VarTD). Species evenness warrants investigation as it considers the relative abundance of species and can have important ecosystem ramifications well before species become locally extinct (Chapin et al., 2000). AvTD is a measure of the average distance between all pairs of species in a taxonomic tree, which captures phenotypic differences and functional richness (Clarke and Warwick, 1999; Rogers et al., 1999). VarTD is the variance of the path lengths between every pair of species in a taxonomic tree, and represents the unevenness of the taxonomic tree (Clarke and Warwick, 2001). Taxonomic hierarchy levels used to measure AvTD and VarTD were Class,
Order, Family, Genus and Species. Path lengths between taxonomic levels were equally weighted.

Total biomass estimates were derived for two key functional groups: piscivores and herbivores. Piscivores were classified as fishes that, based on gut content analyses (Froese and Pauly, 2011) predominantly consume fishes. Piscivores can inhibit increase in abundance of lower trophic level species through predator prey interaction (Jennings et al., 1995; Graham et al., 2003), and are particularly sensitive to fishing pressure (e.g. Jennings and Polunin, 1997; DeMartini et al., 2008; Sandin et al., 2008). Herbivores were classified as those species that predominately feed on large fleshy algae or the epilithic algal matrix (censu Wilson and Bellwood, 1997). This includes fish that remove part of the reef by scraping or excavating the substratum, and grazers that mainly ingest filamentous algae (censu Choat et al., 2002). Herbivores are thought to play a critical role in the resilience of coral reef ecosystems by preventing algal overgrowth that can smother corals (Mumby, 2006; Hughes et al., 2007; Green and Bellwood, 2009). Piscivore and herbivore species were divided into target and non-target species to further explore the effect of fishing on these functional groups. The list of target and non-target species was constructed using expert opinion of Solomon Islands target species (Green et al., 2006b), and creel survey data from adjacent Papua New Guinea (Cinner et al., 2009b) (ESM 1).

\subsection{Proximate drivers}

We measured two proximate drivers previously shown to be related to fish diversity and function: (1) coral cover, and (2) fishing pressure. Coral cover was measured along the same transects used in the fish survey. Substrate type was classified as coral or non-coral at three points at $2 \mathrm{~m}$ intervals along each $50 \mathrm{~m}$ transect totalling 375 points at each site (Hughes, 2006). Coral cover, as a percentage of total substrate, ranged from 13 to $68 \%$ ( mean $=44 \%$ ) among sites. We measured fishing pressure as the number of people selling fish and numbers of fiberglass boats, eskies (insulated ice boxes used for fish preservation), spearguns and fishing nets per coral reef area at each site. We included number of people selling fish as a variable because of evidence that the market-based fishery adversely affects coral reef fish stocks in Solomon Islands (Aswani and Sabetian, 2009; Brewer et al., 2009). Coral reef area was measured using Google Earth Professional, following the methods discussed in Brewer et al. (2009). Fishing pressure variables were consolidated to a single variable $(\lambda=3.3$; variance explained $=65.4 \%$ ) using Principal Components Analysis. All fishing pressure variables loaded positively on the principal component at $\geq 0.65$.

\subsection{Distal drivers}

We developed metrics for three key distal drivers that we hypothesized could strongly influence reef fish assemblages: (1) human population density, (2) socioeconomic development, and (3) market access. Human population density was measured as the total number of inhabitants per coral reef area at each site. Human population density ranged from 11 to 1035 (mean = 159) people per $\mathrm{km}^{2}$ of coral reef. Based on calculated population densities and conservative per capita fish consumption estimates (Bell et al., 2009), eight of the 25 sites exceeded estimated sustainable harvest levels of 5 metric tonnes $\mathrm{km}^{2} \mathrm{yr}^{-1}$ (Newton et al., 2007). Socioeconomic development was measured as the sum of a set of unweighted infrastructures and amenities similar to those used in previous studies (Cinner et al., 2009a; Pollnac et al., 2010); preschool, kindergarten, primary school, high school, clinic, wharf, trade store, supermarket, postal service, fuel depot, credit facility and airport at each site. The infrastructure and amenity variables 
displayed high internal consistency (Cronbach's $\alpha=0.823$ ) allowing aggregation of variables into a single measure of socioeconomic development. The aggregate score for each site was then divided by the number of villages at each respective site, to control for infrastructure and amenity accessibility (Cinner and McClanahan, 2006). Market access was measured as the un-weighted sum of the shortest distance from each ecological sampling location to the nearest local fish market, provincial capital, and national capital, all of which have fish markets, using roads and sea as possible routes within the same distance measure (Brewer et al., 2009).

\subsection{Model construction}

We used partial least squares regression, in the program Warp PLS, to build structural equation models (SEMs) of the general form: distal drivers $\rightarrow$ proximate drivers $\rightarrow$ ecological response.
Partial least squares was chosen over covariance-based approaches primarily because it suited our small sample size (Chin and Newstead, 1999; Reinartz et al., 2009). The distal and proximate drivers remained consistent across models with only the ecological response changing between models (Fig. 2a). All distal drivers (market access, socioeconomic development and population density) were linked to the two proximate drivers (fishing pressure and coral cover), except market access to coral cover as there was no theoretical justification for this link. Both proximate drivers were linked to the ecological response variable in all models. This resulted in unique models for each ecological response; species richness, Pielou's evenness, AvTD, VarTD, total herbivore biomass, non-target herbivore biomass, total piscivore biomass, and nontarget piscivore biomass. The partial least squares method partials out each analysis (e.g. the effect of population density and socioeconomic development on coral cover) from the overall

(a)

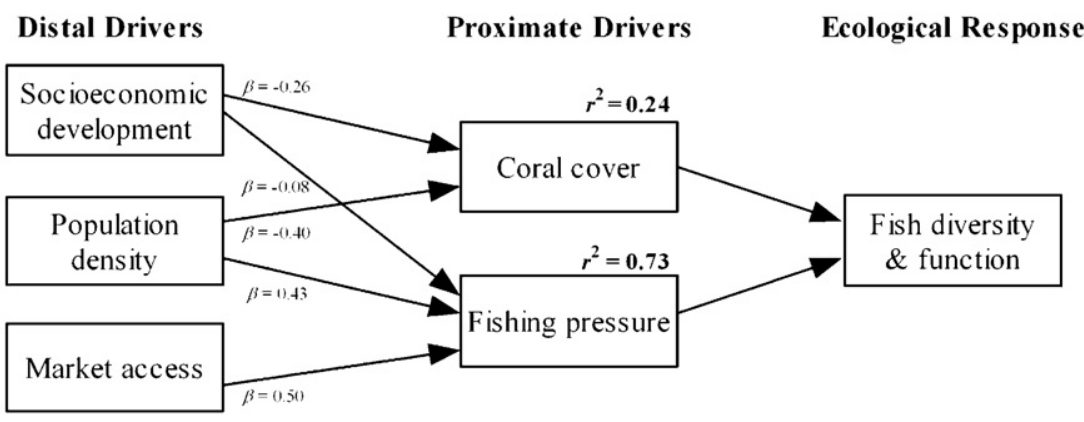

Distal drivers:

Socioeconomic development

Population density

Market access

Proximate drivers:

Coral cover

Fishing pressure

$$
\begin{array}{rrrrr}
-0.6 & -0.4 & -0.2 & 0.0 & 0.2 \\
& \text { Richness }
\end{array}
$$

Distal drivers:

Socioeconomic development

Population density

Market access

Proximate drivers:

Coral cover

Fishing pressure

(e)

(b)
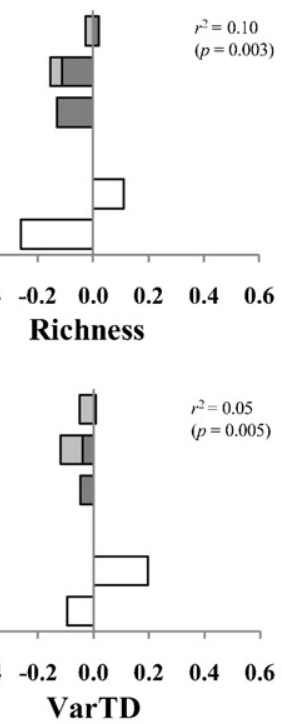

Distal drivers:

Socioeconomic development

Population density

Market access

Proximate drivers:

Coral cover

Fishing pressure (h)

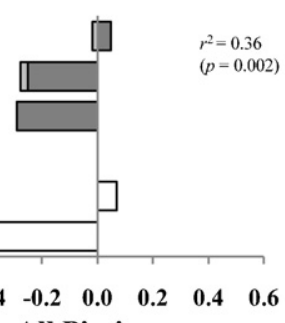

All Piscivore

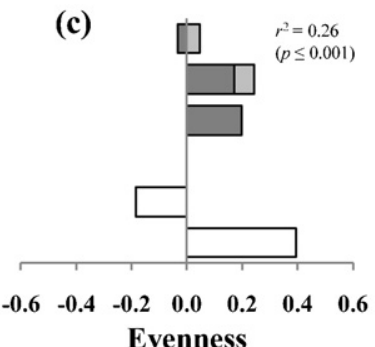

(f)

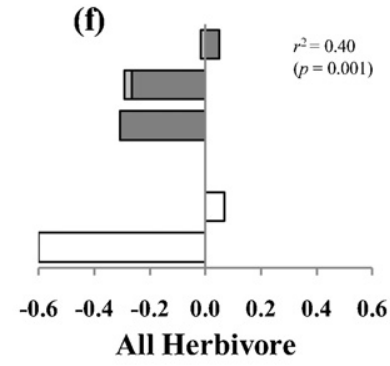

(i)

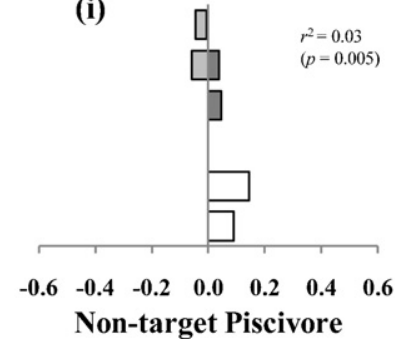

(d)

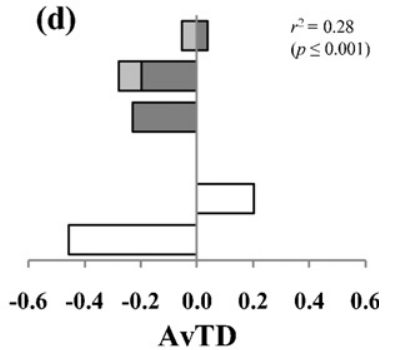

(g)

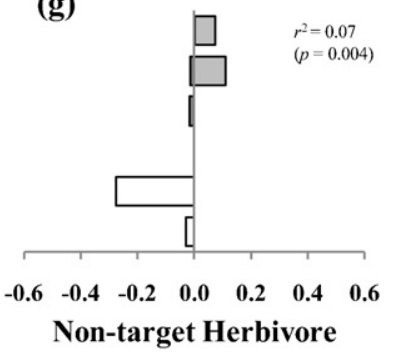

口Indirect effect through coral cover

andirect effect through fishing pressure

$\square$ Direct effect

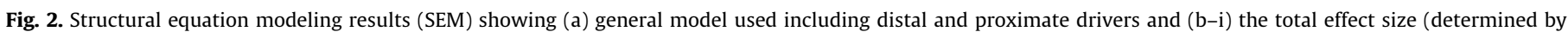

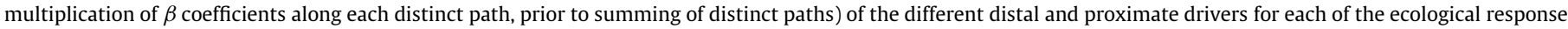

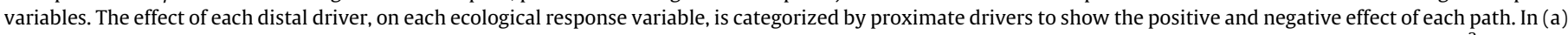

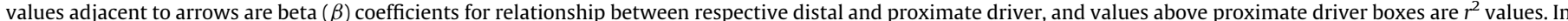

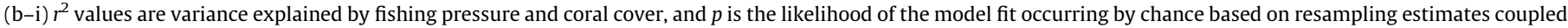
with Bonferroni-like corrections (Kock, 2010). 
model and is therefore, in this study, the equivalent to sets of nonlinear regressions, except that overall model fit statistics are also generated. The models were bootstrapped, set at 100 iterations. We constrained all models to second-order polynomial relationships, thereby allowing simple, non-linear relationships between variables. Warp PLS software has an inbuilt function whereby the relationship between two variables will default to a smaller order polynomial if it is deemed linear (Kock, 2010). The output generated included individual standardized path coefficients $(\beta)$, partial model fit scores $\left(r^{2}\right)$, overall model $p$ values calculated through resampling estimations coupled with Bonferroni-like corrections (Kock, 2010), and individual explanatory and response $x, y$ plots (ESM 2). The total effect of distal drivers (market access, socioeconomic development and population density) were calculated by multiplying the standardized coefficients $(\beta)$ within each pathway then summing these values for pathways associated with each driver.

\section{Results}

\subsection{Effects of proximate drivers on fish function and diversity}

Fishing pressure had a clear negative effect on both fish diversity and the biomass of key functional groups of fish. Specifically, fishing pressure correlated negatively with species richness, and AvTD, and positively with species evenness (Fig. 2bd). Fishing pressure however, did not noticeably affect VarTD, with only a small decrease in VarTD associated with increased fishing pressure (Fig. 2e). Also, fishing pressure had a clear negative effect on both all piscivore and all herbivore biomass, yet non-target biomass of the two functional groups was negligibly affected by fishing pressure (Fig. 2f-i). Coral cover generally had a smaller effect on diversity and functional group metrics than fishing pressure (Fig. 2b-i); Coral cover was positively related to richness, AvTD, VarTD and non-target piscivores. Coral cover was strongly negatively correlated with species evenness and all herbivore biomass (Fig. 2c, g).

\subsection{Effects of distal drivers on fish function and diversity}

Distal drivers explained much of the variance of fishing pressure $\left(r^{2}=0.73\right)$, particularly market access and population density (Fig. 2a). Population density and socioeconomic development were, however, comparatively poor descriptors of coral cover $\left(r^{2}=0.24\right)$. Socioeconomic development had a weak negative effect on fishing pressure and on coral cover, thus had both positive and negative effects on fish diversity and function, except for all herbivore biomass which was positively affected by socioeconomic development through both decreased fishing pressure and decreased coral cover. Population density had a negative effect on all herbivore biomass through increased fishing pressure, and a positive, but weaker, effect on all herbivore biomass through decreased coral cover. Increased market access and population density, more than socioeconomic development, explained decreased diversity and function of coral reef fish (Fig. 2b-i). The strong indirect effect of market access, on diversity and function, was particularly noteworthy because the model specified that market access indirectly affected function and diversity only through fishing pressure, rather than through both fishing pressure and coral cover (Fig. 2a).

\section{Discussion}

This study explored how habitat and social factors explain spatial variability in the diversity and functional group biomass of coral reef fishes at 25 sites across Solomon Islands. Our results demonstrate that population density and market access increase fishing pressure, which is a major driver of fish diversity and functional group biomass. These distal social drivers have a negative effect on the biomass of piscivores and herbivores targeted by fishers. Moreover the relative abundance of species becomes more even, whilst species richness and AvTD decline as population density increases and markets become more accessible.

\subsection{Explaining the effects of proximate drivers on fish function and diversity}

A decline in taxonomic distinctness is often associated with a decline in functional diversity (Rogers et al., 1999; Chapin et al., 2000; Nyström et al., 2000). This is supported here by the finding that fishing pressure had a negative effect on average taxonomic distinctness and the biomass of two important functional groups, herbivores and piscivores. Conversely, there was negligible effect of fishing on non-target species from these functional groups. Thus, the direct effect of fishing is likely to be confined largely to those species and functional groups that are targeted by fishers. A decrease in diversity, and increased evenness with increased fishing pressure, might relate to removal of relatively rare large bodied predators, which are often targeted by fishers (Pauly et al., 1998).

Target species on coral reefs tend to be large bodied (Dulvy et al., 2004b; Graham et al., 2005) and many of the small species have close affiliation with the reef benthos (Munday and Jones, 1998). This is supported by the finding that coral cover and fishing pressure had a similar effect on non-target herbivore and piscivore biomass, compared to all herbivore and all piscivore biomass which was largely explained by fishing pressure alone. For nontarget herbivores the relationship with coral cover was negative, possibly because many of these fish are damselfishes that maintain territories covered with algae (Ceccarelli, 2007) (ESM 1). Conversely, biomass of piscivores, particularly non-targeted species, tended to increase with coral cover. This may be because many smaller bodied non-target predators and their prey take refuge among corals. Indeed a loss of coral and associated structural complexity can lead to declines in small bodied prey fish and their medium sized predators (Graham et al., 2007). Functionally, nontarget species are likely to perform a very different role to the larger bodied species targeted by fishers. Fishing and habitat degradation might therefore have different consequences for both herbivore and piscivore assemblages and the functional services associated with these groups.

\subsection{Explaining the effects of distal drivers on fish function and diversity}

By disaggregating distal and proximate drivers and modeling fish assemblage response to different causal paths of human activity, we have shown that social drivers can have both positive and negative effects on fish communities and their functional role in ecosystems. Population density had both positive and negative effects on all herbivore biomass through coral cover and fishing pressure, respectively. The positive effect, through decreased coral cover, might be explained by increased nutrient levels indirectly caused by high coastal population densities without access to sewage treatment facilities. Resultant excess nutrients have been shown to increase algal growth (e.g. Pastorok and Bilyard, 1985), and consequently increase food availability to herbivores.

Socioeconomic development had a negative effect on coral cover, resulting in marginally reduced species richness and taxonomic distinctness, and increased species evenness and total herbivore biomass. Socioeconomic development however, had a weak negative effect on fishing pressure, leading to marginally 
increased species richness, average taxonomic distinctness, and functional group biomass. Our results are broadly consistent with studies conducted across five Indian Ocean countries that found a decrease in fishing with higher levels of socioeconomic development (Cinner et al., 2009a; Cinner and Bodin, 2010). In comparison to the large socioeconomic development spectrum in these multination studies, the relatively small effect size of socioeconomic development on fishing pressure presented in this study might reflect a small development gradient in Solomon Islands.

The majority of studies that have explored the effect of human activity on coral reef fish diversity and function have shown that these assemblage characteristics are explained by either fishing pressure (Jennings et al., 1995; Jennings and Polunin, 1996; DeMartini et al., 2008) or human population density (Jennings and Polunin, 1997; Bellwood et al., 2003; Dulvy et al., 2004a,b; Mora, 2008; Williams et al., 2008, 2011; Stallings, 2009) (Table 1). While it is clear that local human population density and direct fishing effects are important in explaining ecological gradients, we have shown here that trade, measured as distance to market, is also important (Fig. 2). In the Solomon Islands trade likely affects fish diversity and function through small-scale commercial fishing to supply urban markets, whereas population density likely affects diversity and function through semi-subsistence based fishing to supply local needs. Trade allows societies to acquire resources from further afield, externalizing environmental footprints beyond local human-environment systems (Arrow et al., 1995; Berkes et al., 2006; Shandra et al., 2009). Resource management and biodiversity conservation initiatives must recognize that trade and local population pressure represent different drivers of ecological degradation, and should therefore consider applying different strategies to address their different effects on ecosystems. For example, strong governance of markets through sustainable harvesting certification, and market-specific gear and species restrictions, will become increasingly important if coral reef fish continue to be a readily traded commodity (Berkes et al., 2006).

\subsection{Future model extensions}

Expansion of the models developed in this paper to other socialecological contexts would help to provide a better understanding of how marine ecosystems will respond to key social dynamics. However, three key advancements are necessary to improve the predictive capacity of such models. First, analysis of the indirect effects of distal drivers on the proportionate representation of multiple functional groups (including higher resolution herbivore functional groups such as grazers, scrapers, and excavators) (Wilson and Bellwood, 1997) and species might lend further insight into the role of distal drivers in shaping ecosystem function (Wilson et al., 2008). Second, coral cover is only one measure of coral reef habitat and more detailed models including other environmental and habitat variables (e.g. Wilson et al., 2008), could shed additional light on the relative contribution of distal drivers on diversity and function, particularly for species richness and non-target assemblages of coral reef fish. Third, temporal assessments would be vital to understand the feedbacks that might exist in this system.

\section{Conclusion}

Management measures which address proximate drivers, such as fishing pressure, typically have localized effects on diversity and ecosystem function. Yet, they are limited in their ability to alleviate the effects of distal social drivers such as market access and socioeconomic development (Birkeland, 2004). Therefore, whilst managing proximate threats represents an important (if not limited) management approach, and means of increasing local resilience, governing reefs in a changing world will require becoming better acquainted with the challenges, and potential solutions posed by broader social drivers such as markets and development.

\section{Acknowledgments}

We thank the Australian Research Council Centre of Excellence for Coral Reef Studies for funding this research. Thank you to A. Hughes for providing substrate data. Thank you to the Nature Conservancy and the Solomon Islands statistics office, particularly N. Gagahe for providing data. Thank you to K. Moon and N. Graham for helpful comments on earlier versions of the manuscript.

\section{Appendix A. Supplementary data}

Supplementary data associated with this article can be found, in the online version, at doi:10.1016/j.gloenvcha.2012.01.006.

\section{References}

Agrawal, A., Yadama, G., 1997. How do local institutions mediate market and population pressures on resources? Forest Panchayats in Kumaon, India. Development and Change 28, 435-465.

ANU Enterprise, 2008. People's Survey 2008. Australian National University.

Arrow, K., Bolin, B., Costanza, R., Dasgupta, P., Folke, C., Holling, C.S., Jansson, B.-O., Levin, S., Mäler, K.-G., Perrings, C., Pimentel, D., 1995. Economic growth, carrying capacity, and the environment. Ecological Economics 15, 91-95.

Aswani, S., 1999. Common property models of sea tenure: a case study from the Roviana and Vonavona Lagoons, New Georgia, Solomon Islands. Human Ecology 27, 417-453.

Aswani, S., Sabetian, A., 2009. Implications of urbanization for artisanal parrotfish fisheries in the Western Solomon Islands. Conservation Biology 24, 520-530.

Aswani, S., 2011. Socioecological approaches for combining ecosystem-based and customary management in Oceania. Journal of Marine Biology, doi:10.1155/ $2011 / 845385$.

Bell, J.D., Galzin, R., 1984. Influence of live coral cover on coral-reef fish communities. Marine Ecology Progress Series 15, 265-274.

Bell, J.D., Kronen, M., Vunisea, A., Nash, W.J., Keeble, G., Demmke, A., Pontifex, S. Andréfouët, S., 2009. Planning the use of fish for food security in the Pacific. Marine Policy 33, 64-76.

Bellwood, D.R., Hoey, A.S., Choat, J.H., 2003. Limited functional redundancy in high diversity systems: resilience and ecosystem function on coral reefs. Ecology Letters 6, 281-285.

Bellwood, D.R., Hughes, T.P., 2001. Regional-scale assembly rules and biodiversity of coral reefs. Science 292, 1532-1535.

Bellwood, D.R., Hughes, T.P., Connolly, S.R., Tanner, J., 2005. Environmental and geometric constraints on Indo-Pacific coral reef biodiversity. Ecology Letters 8, 643-651.

Bellwood, D.R., Hughes, T.P., Hoey, A.S., 2006. Sleeping functional group drives coral-reef recovery. Current Biology 16, 2434-2439.

Berkes, F., Hughes, T.P., Steneck, R.S., Wilson, J.A., Bellwood, D.R., Crona, B., Folke, C., Gunderson, L.H., Leslie, H.M., Norberg, J., Nyström, M., Olsson, P., Österblom, H. Scheffer, M., Worm, B., 2006. Globalization, roving bandits, and marine resources. Science 311, 1557-1558.

Birkeland, C., 2004. Ratcheting down the coral reefs. BioScience 54, 1021-1027.

Brewer, T.D., Cinner, J.E., Green, A., Pandolfi, J.M., 2009. Thresholds and multiple scale interaction of environment, resource use, and market proximity on reef fishery resources in the Solomon Islands. Biological Conservation 142, 17971807.

Cardinale, B.J., Srivastava, D.S., Emmett Duffy, J., Wright, J.P., Downing, A.L., Sankaran, M., Jouseau, C., 2006. Effects of biodiversity on the functioning of trophic groups and ecosystems. Nature 443, 989-992.

Ceccarelli, D., 2007. Modification of benthic communities by territorial damselfish: a multi-species comparison. Coral Reefs 26, 853-866.

Chapin III, F.S., Zavaleta, E.S., Eviner, V.T., Naylor, R.L., Vitousek, P.M., Reynolds, H.L., Hooper, D.U., Lavorel, S., Sala, O.E., Hobbie, S.E., Mack, M.C., Diaz, S., 2000 Consequences of changing biodiversity. Nature 405, 234-242.

Chin, W.W., Newstead, P.R., 1999. Structural equation modeling analysis with small samples using partial least squares. In: Hoyle, R.H. (Ed.), Statistical Strategies for Small Sample Research. Sage, Thousand Oaks, CA.

Choat, J.H., Clements, K.D., Robbins, W.D., 2002. The trophic status of herbivorous fishes on coral reefs. 1: Dietary analyses. Marine Biology 140, 613-623.

Cinner, J.E., McClanahan, T.R., 2006. Socioeconomic factors that lead to overfishing in small-scale coral reef fisheries of Papua New Guinea. Environmental Conservation $33,73-80$. 
Cinner, J.E., McClanahan, T.R., Daw, T.M., Graham, N.A.J., Maina, J., Wilson, S.K., Hughes, T.P., 2009a. Linking social and ecological systems to sustain coral reef fisheries. Current Biology 19, 206-212.

Cinner, J.E., McClanahan, T.R., Graham, N.A.J., Pratchett, M.S., Wilson, S.K., Raina, J.B., 2009b. Gear-based fisheries management as a potential adaptive response to climate change and coral mortality. Journal of Applied Ecology 46, 724-732.

Cinner, J.E., Bodin, Ö., 2010. Livelihood diversification in tropical coastal communities: a network-based approach to analyzing 'Livelihood Landscapes'. PLoS ONE 5, e11999.

Clarke, K.R., Warwick, R.M., 1999. The taxonomic distinctness measure of biodiversity: weighting of step lengths between hierarchical levels. Marine Ecology Progress Series 184, 21-29.

Clarke, K.R., Warwick, R.M., 2001. A further biodiversity index applicable to species lists: variation in taxonomic distinctness. Marine Ecology Progress Series 216, 265-278.

Connolly, S.R., Bellwood, D.R., Hughes, T.P., 2003. Indo-pacific biodiversity of coral reefs: deviations from a mid-domain model. Ecology 84, 2178-2190.

DeMartini, E.E., Friedlander, A.M., Sandin, S.A., Sala, E., 2008. Differences in fishassemblage structure between fished and unfished atolls in the northern Line Islands, central Pacific. Marine Ecology Progress Series 365, 199-215.

Dulvy, N.K., Freckleton, R.P., Polunin, N.V.C., 2004a. Coral reef cascades and the indirect effects of predator removal by exploitation. Ecology Letters 7, 410-416.

Dulvy, N.K., Polunin, N.V.C., Mill, A.C., Graham, N.A.J., 2004b. Size structural change in lightly exploited coral reef fish communities: evidence for weak indirect effects. Canadian Journal of Fisheries and Aquatic Sciences 61, 466-475.

Floeter, S.R., Krohling, W., Gasparini, J.L., Ferreira, C.E., Zalmon, I.R., 2007. Reef fish community structure on coastal islands of the southeastern Brazil: the influence of exposure and benthic cover. Environmental Biology of Fishes 78, 147160.

Forester, D.J., Machlis, G.E., 1996. Modeling human factors that affect the loss of biodiversity. Conservation Biology 10, 1253-1263.

Friedlander, A.M., Brown, E.K., Jokiel, P.L., Smith, W.R., Rodgers, K.S., 2003. Effects of habitat, wave exposure, and marine protected area status on coral reef fish assemblages in the Hawaiian archipelago. Coral Reefs 22, 291-305.

Friedlander, A.M., Parrish, J.D., 1998. Habitat characteristics affecting fish assemblages on a Hawaiian coral reef. Journal of Experimental Marine Biology and Ecology 224, 1-30.

Froese, R., Pauly, D., 2011. Fishbase. World Wide Web Electronic Publication (accessed 07.2011)www.fishbase.org.

Fulton, C.J., Bellwood, D.R., 2005. Wave-induced water motion and the functional implications for coral reef fish assemblages. Limnology and Oceanography 50 255-264.

Geist, H.J., Lambin, E.F., 2002. Proximate causes and underlying driving forces of tropical deforestation. BioScience 52, 143-150.

Graham, N.A.J., Dulvy, N.K., Jennings, S., Polunin, N.V.C., 2005. Size-spectra as indicators of the effects of fishing on coral reef fish assemblages. Coral Reefs $24,118-124$

Graham, N.A.J., Evans, R.D., Russ, G.R., 2003. The effects of marine reserve protection on the trophic relationships of reef fishes on the Great Barrier Reef. Environmental Conservation 30, 200-208.

Graham, N.A.J., McClanahan, T.R., MacNeil, M.A, Wilson, S.K., Polunin, N.V.C. Jennings, S., Chabanet, P., Clark, S., Spalding, M.D., Letourneur, Y., Bigot, L., Galzin, R., öhman, M.C., Garpe, K.C., Edwards, A.J., Sheppard, C.R.C., 2008 Climate warming, marine protected areas and the ocean-scale integrity of coral reef ecosystems. PLoS ONE 3, e3039.

Graham, N.A.J., Wilson, S.K., Jennings, S., Polunin, N.V.C., Bijoux, J.P., Robinson, J., 2006. Dynamic fragility of oceanic coral reef ecosystems. Proceedings of the National Academy of Sciences 103, 8425-8429.

Graham, N.A.J., Wilson, S.K., Jennings, S., Polunin, N.V.C., Robinson, J.A.N., Bijoux, J.P., Daw, T.M., 2007. Lag effects in the impacts of mass coral bleaching on coral reef fish, fisheries, and ecosystems. Conservation Biology 21, 1291-1300.

Gratwicke, B., Speight, M.R., 2005. The relationship between fish species richness, abundance and habitat complexity in a range of shallow tropical marine habitats. Journal of Fish Biology 66, 650-667.

Green, A., Bellwood, D.R., 2009. Monitoring Functional Groups of Herbivorous Ree Fishes as Indicators of Coral Reef Resilience - A Practical Guide for Coral Ree Managers in the Asia Pacific Region. IUCN, Gland, Switzerland.

Green, A., Lokani, P., Atu, W., Ramohia, P., Thomas, P., Almany, J., 2006a. Solomon Islands Marine Assessment: Technical Report of Survey Conducted May 13 to June 17, 2004. TNC Pacific Island Countries Report No. 1/06.

Green, A., Ramohia, P., Ginigele, M., Leve, T., 2006b. Fisheries resources: coral reef fishes. In: Green, A., Lokani, P., Atu, W., Ramohia, P., Thomas, P., Almany, J. (Eds.), Solomon Islands Marine Assessment: Technical Report of Survey Conducted May 13 to June 17, 2004. TNC Pacific Island Countries Report No. 1/06.

Hoey, A.S., Bellwood, D.R., 2009. Limited functional redundancy in a high diversity system: single species dominates key ecological process on coral reefs. Ecosystems $12,1316-1328$.

Hooper, D.U., Chapin, F.S., Ewel, J.J., Hector, A., Inchausti, P., Lavorel, S., Lawton, J.H., Lodge, D.M., Loreau, M., Naeem, S., Schmid, B., Setälä, H., Symstad, A.J., Vandermeer, J., Wardle, D.A., 2005. Effects of biodiversity on ecosystem functioning: a consensus of current knowledge. Ecological Monographs 75, 3-35.

Hughes, A., 2006. Benthic Communities, Solomon Islands Marine Assessment: Technical Report of Survey Conducted May 13 to June 17, 2004. TNC Pacific Island Countries Report No. 1/06.

Hughes, T.P., 1994. Catastrophes, phase shifts, and large-scale degradation of a Caribbean coral reef. Science 265, 1547-1551.
Hughes, T.P., Rodrigues, M.J., Bellwood, D.R., Ceccarelli, D., Hoegh-Guldberg, O., McCook, L., Moltschaniwskyj, N., Pratchett, M.S., Steneck, R.S., Willis, B., 2007. Phase shifts, herbivory, and the resilience of coral reefs to climate change. Current Biology 17, 360-365.

Ives, A.R., Carpenter, S.R., 2007. Stability and diversity of ecosystems. Science 317, 58-62.

Jennings, S., Grandcourt, E.M., Polunin, N.V.C., 1995. The effects of fishing on the diversity, biomass and trophic structure of Seychelles' reef fish communities. Coral Reefs 14, 225-235.

Jennings, S., Polunin, N.V.C., 1997. Impacts of predator depletion by fishing on the biomass and diversity of non-target reef fish communities. Coral Reefs 16, 71-82.

Jennings, S., Polunin, N.V.C., 1996. Effects of fishing effort and catch rate upon the structure and biomass of Fijian reef fish communities. Journal of Applied Ecology 33, 400-412.

Jones, G.P., Planes, S., Thorrold, S.R., 2005. Coral reef fish larvae settle close to home. Current Biology 15, 1314-1318.

Kock, N., 2010. WarpPLS $\odot 1.0$ User Manual. ScriptWarp Systems, Laredo, TX.

Kramer, D.B., Urquhart, G., Schmitt, K., 2009. Globalization and the connection of remote communities: a review of household effects and their biodiversity implications. Ecological Economics 68, 2897-2909.

Luckhurst, B.E., Luckhurst, K., 1978. Analysis of the influence of substrate variables on coral reef fish communities. Marine Biology 49, 317-323.

Maestre, F.T., Quero, J.L., Gotelli, N.J., Escudero, A., Ochoa, V., Delgado-Baquerizo, M. García-Gómez, M., Bowker, M.A., Soliveres, S., Escolar, C., García-Palacios, P. Berdugo, M., Valencia, E., Gozalo, B., Gallardo, A., Aguilera, L., Arredondo, T., Blones, J., Boeken, B., Bran, D., Conceição, A.A., Cabrera, O., Chaieb, M., Derak, M., Eldridge, D.J., Espinosa, C.I., Florentino, A., Gaitán, J., Gatica, M.G., Ghiloufi, W., Gómez-González, S., Gutiérrez, J.R., Hernández, R.M., Huang, X., Huber-Sannwald, E., Jankju, M., Miriti, M., Monerris, J., Mau, R.L., Morici, E., Naseri, K., Ospina, A Polo, V., Prina, A, Pucheta, E, Ramírez-Collantes, D.A., Romão, R., Tighe, M., Torres-Díaz, C., Val, J., Veiga, J.P., Wang, D., Zaady, E., 2012. Plant species richness and ecosystem multifunctionality in global drylands. Science $335,214-218$.

McCann, K.S., 2000. The diversity-stability debate. Nature 405, 228-233.

McClanahan, T.R., Maina, J.M., Muthiga, N.A., 2011. Associations between climate stress and coral reef diversity in the western Indian Ocean. Global Change Biology 17, 2023-2032.

McKinney, L.A., Kick, E.L., Fulkerson, G.M., 2010. World system, anthropogenic, and ecological threats to bird and mammal species: a structural equation analysis of biodiversity loss. Organization and Environment 23, 3-31.

Molles Jr., M.C., 1978. Fish species diversity on model and natural reef patches: experimental insular biogeography. Ecological Monographs 48, 289-305.

Mora, C., 2008. A clear human footprint in the coral reefs of the Caribbean. Proceedings of the Royal Society B: Biological Sciences 275, 767-773.

Mora, C., Aburto-Oropeza, O., Ayala Bocos, A., Ayotte, P.M., Banks, S., Bauman, A.G., Beger, M., Bessudo, S., Booth, D.J., Brokovich, E., Brooks, A., Chabanet, P., Cinner, J.E., Cortés, J., Cruz-Motta, J.J., Cupul Magaña, A., DeMartini, E.E., Edgar, G.J., Feary, D.A., Ferse, S.C.A., Friedlander, A.M., Gaston, K.J., Gough, C., Graham, N.A.J., Green, A., Guzman, H., Hardt, M., Kulbicki, M., Letourneur, Y., López Pérez, A., Loreau, M., Loya, Y., Martinez, C., Mascareñas-Osorio, I., Morove, T., Nadon, M.O., Nakamura, Y., Paredes, G., Polunin, N.V.C., Pratchett, M.S., Reyes Bonilla, H.c., Rivera, F., Sala, E., Sandin, S.A., Soler, G., Stuart-Smith, R., Tessier, E., Tittensor, D.P., Tupper, M., Usseglio, P., Vigliola, L., Wantiez, L., Williams, I., Wilson, S.K., Zapata, F.A., 2011. Global human footprint on the linkage between biodiversity and ecosystem functioning in reef fishes. PLoS Biology 9, e1000606.

Mora, C., Chittaro, P.M., Sale, P.F., Kritzer, J.P., Ludsin, S.A., 2003. Patterns and processes in reef fish diversity. Nature 421, 933-936.

Mora, C., Robertson, D.R., 2005. Causes of latitudinal gradients in species richness: a test with fishes of the tropical Eastern Pacific. Ecology 86, 1771-1782.

Muller, D., Zeller, M., 2002. Land use dynamics in the central highlands of Vietnam: a spatial model combining village survey data with satellite imagery interpretation. Agricultural Economics 27, 333-354.

Mumby, P.J., 2006. The impact of exploiting grazers (Scaridae) on the dynamics of Caribbean coral reefs. Ecological Applications 16, 747-769.

Munday, P.L., Jones, G.P., 1998. The ecological implications of small body size among coral-reef fishes. Oceanography and Marine Biology Annual Review 36, 373-411.

Naeem, S., 1998. Species redundancy and ecosystem reliability. Conservation Biology 12, 39-45.

Newton, K., Cote, I.M., Pilling, G.M., Jennings, S., Dulvy, N.K., 2007. Current and future sustainability of island coral reef fisheries. Current Biology 17, 655-658.

Nyström, M., Folke, C., Moberg, F., 2000. Coral reef disturbance and resilience in a human-dominated environment. Trends in Ecology and Evolution 15, 413-417.

Öhman, M.C., Rajasuriya, A., 1998. Relationships between habitat structure and fish communities on coral and sandstone reefs. Environmental Biology of Fishes 53, $19-31$.

Pandolfi, J.M., Bradbury, R.H., Sala, E., Hughes, T.P., Bjorndal, K.A., Cooke, R.G., McArdle, D., McClenachan, L., Newman, M.J.H., Paredes, G., Warner, R.R., Jackson, J.B.C., 2003. Global trajectories of the long-term decline of coral reef ecosystems. Science 301, 955-958.

Pastorok, R.A., Bilyard, G.R., 1985. Effects of sewage pollution on coral-reef communities. Marine Ecology Progress Series 21, 175-189.

Pauly, D., Christensen, V., Dalsgaard, J., Froese, R., Torres, F., 1998. Fishing down marine food webs. Science 279, 860-863.

Pollnac, R., Christie, P., Cinner, J.E., Dalton, T., Daw, T.M., Forrester, G.E., Graham, N.A.J., McClanahan, T.R., 2010. Marine reserves as linked social-ecological systems. Proceedings of the National Academy of Sciences 107, 18262-18265. 
Reinartz, W., Haenlein, M., Henseler, J., 2009. An empirical comparison of the efficacy of covariance-based and variance-based SEM. International Journal of Research in Marketing 26, 332-344.

Roberts, C.M., Ormond, R.F.G., 1987. Habitat complexity and coral reef fish diversity and abundance on Red Sea fringing reefs. Marine Ecology Progress Series 41,1-8.

Rogers, S.I., Clarke, K.R., Reynolds, J.D., 1999. The taxonomic distinctness of coastal bottom-dwelling fish communities of the North-east Atlantic. Journal of Animal Ecology 68, 769-782.

Russ, G.R., 2003. Grazer biomass correlates more strongly with production than with biomass of algal turfs on a coral reef. Coral Reefs 22, 63-67.

Sandin, S.A., Smith, J.E., DeMartini, E.E., Dinsdale, E.A., Donner, S.D., Friedlander, A.M., Konotchick, T., Malay, M., Maragos, J.E., Obura, D., Pantos, O., Paulay, G., Richie, M., Rohwer, F., Schroeder, R.E., Walsh, S., Jackson, J.B.C., Knowlton, N., Sala, E., 2008. Baselines and degradation of coral reefs in the northern line islands. PLoS ONE 3, e1548.

Shandra, J.M., Leckband, C., McKinney, L.A., London, B., 2009. Ecologically unequal exchange, world polity, and biodiversity loss. International Journal of Comparative Sociology 50, 285-310.

Stallings, C.D., 2009. Fishery-independent data reveal negative effect of human population density on Caribbean predatory fish communities. PLoS ONE 4, e5333.
Tilman, D., Reich, P.B., Knops, J.M.H., 2006. Biodiversity and ecosystem stability in a decade-long grassland experiment. Nature 441, 629-632.

Williams, I.D., Richards, B.L., Sandin, S.A., Baum, J.K., Schroeder, R.E., Nadon, M.O., Zgliczynski, B., Craig, P., Mcllwain, J.L., Brainard, R.E., 2011. Differences in reef fish assemblages between populated and remote reefs spanning multiple archipelagos across the central and Western Pacific. Journal of Marine Biology 14.

Williams, I.D., Walsh, W.J., Schroeder, R.E., Friedlander, A.M., Richards, B.L., Stamoulis, K.A., 2008. Assessing the importance of fishing impacts on Hawaiian coral reef fish assemblages along regional-scale human population gradients. Environmental Conservation 35, 261-272.

Wilson, S., Bellwood, D.R., 1997. Cryptic dietary components of territorial damselfishes (Pomacentridae, Labroidei). Marine Ecology Progress Series 153, 299310.

Wilson, S.K., Fisher, R., Pratchett, M.S., Graham, N.A.J., Dulvy, N.K., Turner, R.A., Cakacaka, A., Polunin, N.V.C., Rushton, S.P., 2008. Exploitation and habitat degradation as agents of change within coral reef fish communities. Global Change Biology 14, 2796-2809.

Wilson, S.K., Graham, N.A.J., Pratchett, M.S., Jones, G.P., Polunin, N.V.C., 2006. Multiple disturbances and the global degradation of coral reefs: are reef fishes at risk or resilient? Global Change Biology 12, 2220-2234. 